\title{
Kadar Fe Organik dan P Tersedia pada Tanah Sawah Rawa Lebak yang Diaplikasi Kompos dan Pengelolaan Air di Poso
}

\author{
Ita Mowidu* \\ Program Studi Agroteknologi, Fakultas Pertanian, Universitas Sintuwu Maroso \\ *Corresponding author: itamowidu@unsimar.ac.id
}

\begin{abstract}
Non-tidal swamp rice field in Poso contain total Fe in a very high amount, ranging from $1,16 \%$ to $2,26 \%$. In a reductive or very reductive condition, $F$ e solubility will be extremely high beyond the level where paddy can tolerate, hence causing toxicity in paddy. Application of compost is expected to chelate Fe and form organic Fe to decrease toxic effect in paddy. A greenhouse experiment was done treatment by 5 ton/ha of straw compost and cocoa pod compost in various combination to non-tidal swamp rice field in Korobono Poso regency. Under this factorial treatment, the first factor was composition of compost ( $100 \%$ straw compost, $75 \%$ straw compost $+25 \%$ cocoa pods compost, $50 \%$ straw compost + $50 \%$ cocoa pods compost, $25 \%$ straw compost $+75 \%$ cocoa pods compost, and $100 \%$ cocoa pods compost), and the second factor was water management (saturated irrigation and intermittent), arranged under completely randomized design (CRD). The observed component was the level of organic $F e$ and available $P$ in soil. The research finding showed that the application of compost to non-tidal swamp rice field in Poso increased the level of organic Fe and available $P$ in soil. The level of organic $F e$ and available $P$ in soil with saturated irrigation was higher than with intermittent irrigation. The increased organic Fe tended to increased available P in the soil in non-tidal swamp rice field in Poso.
\end{abstract}

Keywords: Available P; Compost; Non-tidal swamp; Organic Fe; Water management

Cite this as: Mowidu, I. 2018. Kadar Fe Organik dan P Tersedia pada Tanah Sawah Rawa Lebak yang Diaplikasi Kompos dan Pengelolaan Air di Poso. Caraka Tani: Journal of Sustainable Agriculture. 33(1), $26-33$. doi:http://dx.doi.org/10.20961/carakatani.v33i1.19458

\section{PENDAHULUAN}

Luas lahan rawa lebak di Indonesia 13,296 juta ha. Dari luasan tersebut terdapat 0,644 juta ha di Sulawesi. Menurut Widjaja-Adhi (dalam Noor, 2007) baru 0,002 juta ha lahan rawa lebak di Sulawesi yang dikembangkan untuk pertanian dalam arti luas sehingga masih 0,642 juta yang belum dikembangkan. Irianto (2006 dalam Noor, 2007) menyatakan luas lahan rawa lebak di Sulawesi Tengah yang telah dikembangkan untuk berbagai usaha pertanian adalah 4.675 ha. Data tersebut menunjukkan bahwa dalam kurun waktu tahun 2000 sampai 2006, rawa lebak di Sulawesi (termasuk Sulawesi Tengah) terus dikembangkan untuk usaha pertanian.

Rawa lebak di Sulawesi Tengah, khususnya di Kabupaten Poso, tersebar dari dataran rendah sampai dataran tinggi. Dari luas daratan kabupaten Poso sebesar 871.225 ha terdapat 22.190 ha sebagai lahan sawah (BPS, 2011).
Sebagian besar dari luas lahan sawah tersebut merupakan rawa lebak yang terbentuk karena curah hujan tinggi dan terletak pada cekungan di antara gunung dan atau di antara sungai dan atau danau.

Menurut Suparwoto dan Waluyo (2009) lahan lebak berpotensi besar untuk pengembangan tanaman pangan, hortikultura, peternakan dan perikanan. Pengembangan pertanian padi sawah di Kabupaten Poso mengalami hambatan. Lahan rawa di Kabupaten Poso mengandung Fe total sangat tinggi, yaitu 1,16-2,26\% (Mowidu et al., 2015). Menurut Patrick dan Reddy (1978) sifat kimia tanah sawah yang mengandung Fe tinggi lebih didominasi oleh sifat besi daripada unsurunsur lain. Jumlah besi dalam tanah yang dapat tereduksi sangat banyak, yaitu 10 kali lebih banyak dari total unsur-unsur lain yang dapat direduksi. Akibatnya kelarutan $\mathrm{Fe}$ tinggi dan berpotensi menyebabkan keracunan pada padi sawah. 
Di Indonesia, keracunan Fe pada tanaman padi sawah ditemukan di beberapa daerah sentra padi seperti Jawa Barat, Jawa Timur, Lampung, Sumatera Selatan, Bengkulu, Riau, Jambi, Sumatera Barat, Kalimantan Barat, Kalimantan Timur, Kalimantan Selatan, Sulawesi Tenggara dan Sulawesi Tengah dengan luas sekitar 1 juta hektar (Andiantoro \& Slamet, 1991; Ismunadji, 1990). Pada tanah yang kaya Fe, suasana reduktif menyebabkan kelarutan $\mathrm{Fe}$ tinggi dan menyebabkan keracunan pada tanaman padi (Nawas et al., 2014).

Menurut Ethan et al. (2011) keracunan $\mathrm{Fe}$ adalah penghambat utama produksi padi sawah dalam kondisi tergenang, berhubungan dengan kelebihan $\mathrm{Fe}^{2+}$ dalam tanah, drainase jelek, Eh rendah (Ottow et al., 1982; Ponnamperuma, 1994), defisiensi $\mathrm{P}, \mathrm{Zn}$ dan keracunan $\mathrm{H}_{2} \mathrm{~S}$ (Kirk, 2004), oksigen tanah rendah (Ponnamperuma et al., 1967), status hara tanaman rendah dan tidak seimbang (Benckiser et al., 1982; Yamauchi, 1989) dan pemberian bahan organik yang tidak mudah terdekomposisi (Dobermann dan Fairhurst, 2000; Fairhurst et al., 2002).

Kandungan Fe dalam tanaman yang keracunan dapat mencapai $2000 \mathrm{mg} / \mathrm{kg}$ (Dobermann \& Fairhurst, 2000; Sahrawat, 2000) dan dapat menurunkan hasil. Penurunan hasil akibat keracunan Fe berkisar 50\% (Audebert, 2006), 52\% (Ismunadji et al., 1973), $30-100 \%$ tergantung pada toleransi varietas terhadap $\mathrm{Fe}$, intensitas keracunan $\mathrm{Fe}$, dan status kesuburan tanah (Indradewa et al., 2010) atau $12-100 \%$ tergantung varietas dan tingkat keracunan (Gunawardena et al., 1982; Masajo et al., 1986; Abifarin, 1988; Sahrawat, 2004).

Penurunan hasil padi akibat keracunan $\mathrm{Fe}$ dapat dikurangi melalui pengendalian kelarutan Fe dan peningkatan ketersediaan P. Pengendalian kelarutan $\mathrm{Fe}$ dan peningkatan ketersediaan $\mathrm{P}$ dapat dilakukan dengan cara pengelolaan air irigasi, penggunaan bahan organik dan peningkatan $\mathrm{pH}$ tanah. Menurut Sahrawat (2012) penggenangan menetralisir tanah-tanah bermasalah, dimana $\mathrm{pH}$ umumnya stabil pada $\mathrm{pH}$ sekitar netral $(6,5$ - 7,5), dan meningkatkan ketersediaan hara $\mathrm{N}$-amonium, $\mathrm{P}, \mathrm{K}, \mathrm{Ca}, \mathrm{Mg}, \mathrm{Fe}$, $\mathrm{Mn}$ dan Si. Untuk mengurangi serapan $\mathrm{P}$ maka $\mathrm{pH}$ dinaikkan sampai sekitar 5,5 dan lokasi serapan dijenuhi dengan anion kompetitor lain, seperti anion organik yang berasal dari dekomposisi bahan organik.
Bahan organik yang dapat digunakan untuk mengendalikan kelarutan $\mathrm{Fe}$ dan meningkatkan ketersediaan $\mathrm{P}$ antara lain kompos jerami dan kulit buah kakao. Menurut Murthy et al. (2010) bahan organik meningkatkan ketersediaan hara tanaman melalui peningkatan kegiatan biokimia mikroorganisme. Kelarutan fosfat tanah cenderung maksimum pada kisaran pH $6-7$ (Ponnamperuma, 1977), 6,0 - 6,5 (Havlin et al., 2005), 5,5 - 6,5 (Prasad dan Power, 1977). Menurut Patrick dan Reddy (1978) kelarutan maksimum fosfat yang ditambahkan dan fosfat asli tanah (native soil $P$ ) pada tanah tergenang pada $\mathrm{pH} 5$.

Kajian ini mempelajari kadar $\mathrm{Fe}$ dan ketersediaan $\mathrm{P}$ pada tanah sawah rawa dengan kadar Fe tinggi yang diberi dengan sistem pengairan yang berbeda. Selain itu, ingin mengetahui serapan hara $\mathrm{P}$ dan Fe oleh tanaman padi serta pengaruhnya terhadap hasil padi.

\section{METODE PENELITIAN}

Percobaan rumah kaca 2 faktor, yaitu faktor kompos 5 ton/ha (K0: tanpa pemberian kompos, K1: kompos jerami 100\%, K2: kompos jerami $75 \%$ + kulit buah kakao 25\%, K3: kompos jerami $50 \%$ + kulit buah kakao 50\%, K4: kompos jerami $25 \%$ + kulit buah kakao 75\%, dan K5: kompos kulit buah kakao 100\%), dan cara pengairan (I1: macak-macak dan I2: intermittent telah dilakukan di Poso. Tiap perlakuan diulang 3 kali, kecuali Kontrol, sehingga terdapat $5 \times 2 \times 3+2$ kontrol $=$ 32 unit percobaan.

Unit-unit percobaan diatur menurut pola rancangan acak lengkap (RAL). Wadah media tanam menggunakan bak plastik berdiameter sekitar $56 \mathrm{~cm}$ dan ember berdiameter sekitar 20 $\mathrm{cm}$, yang diisi tanah kering udara lolos ayakan 2 mm sebanyak $15 \mathrm{~kg}$ dan $2 \mathrm{~kg}$, yang dicampur secara homogen dengan kompos 5 ton/ha sesuai perlakuan pada 2 minggu sebelum tanam. Sebagai pupuk basal diberikan pupuk $\mathrm{N}$ sebanyak 90 $\mathrm{kg} / \mathrm{ha}, \mathrm{P}_{2} \mathrm{O}_{5}$ sebanyak $60 \mathrm{~kg} / \mathrm{ha}$, dan $\mathrm{K}_{2} \mathrm{O}$ sebanyak $60 \mathrm{~kg} / \mathrm{ha}$. Urea diberikan secara bertahap, yaitu $1 / 3$ bagian diberikan bersamaan dengan semua takaran pupuk $\mathrm{P}$ dan $\mathrm{K}$ pada 7 hari setelah tanam (HST), 1/3 bagian lagi diberikan pada 28 HST dan sisanya $1 / 3$ bagian diberikan pada 56 HST. Bibit padi berumur 15 hari setelah sebar ditanam 3 batang per rumpun, 4 rumpun tiap pot besar dengan jarak tanam $20 \mathrm{~cm}$ x $20 \mathrm{~cm}$, dan 1 rumpun tiap pot kecil. 
Untuk pengairan digunakan air sumur bor dan pemberiannya sesuai perlakuan. Pada perlakuan pengairan macak-macak (I1), selama pertumbuhan sampai 7 hari sebelum panen, tanah dipertahankan dalam keadaan macak-macak. Pada perlakuan pengairan berselang (I2) pemberian air diatur sebagai berikut: pada saat tanam sampai 7 HST air dipertahankan dalam keadaan macak-macak. Pada 8 HST pot diberi air setinggi $3 \mathrm{~cm}$ dan dipertahankan pada ketinggian itu sampai umur 55 HST. Pada 56 HST, mengakhiri fase anakan maksimum, air genangan dikeluarkan sampai tanah dalam keadaan macakmacak hingga umur 62 HST. Pada 63 HST, pada saat padi memasuki fase primordia, pot diberi air lagi setinggi $5 \mathrm{~cm}$ sampai umur 76 HST. Pada 77 HST, pada saat padi mulai berbunga, air genangan dibuang lagi sampai macak-macak sampai umur 83 HST. Pada 84 HST selama pengisian biji, pot digenangi lagi setinggi $5 \mathrm{~cm}$ sampai umur 98 HST. Untuk menyeragamkan pemasakan maka pada 99 HST, pada saat malai mulai menguning, pot dikeringkan.

Pengamatan dilakukan terhadap $\mathrm{Fe}$ organik (Fe-p) dan $\mathrm{P}$ tersedia (P tsd) sampel tanah kering udara yang diambil pada 14, 40, 70, 75 HST dan saat panen. Juga diamati serapan $\mathrm{P}$ dan Fe padi. Untuk mengetahui kadar Fe organik digunakan pengekstrak 0.1 M Na-pirofosfat. P tsd ditentukan dengan metode Bray-1. Analisis tanah dilakukan di Laboratorium Balai Penelitian Tanah, Bogor.

Analisis data uji $\mathrm{F}$ dan uji Duncan dilakukan dengan perangkat lunak SAS for Windows versi 9.1. Uji regresi dan korelasi sederhana untuk melihat hubungan antara $\mathrm{P}$ tersedia dan $\mathrm{Fe}$ organik dalam tanah menggunakan perangkat lunak SPSS versi 16.0.

\section{HASIL DAN PEMBAHASAN}

\section{Kadar Fe Organik}

Hasil penelitian menunjukkan bahwa aplikasi kompos berpengaruh sangat nyata terhadap kadar Fe organik tanah pada umur 40 dan 70 HST, sedangkan pengelolaan air berpengaruh sangat nyata pada umur 40, 70, 75 HST dan saat panen. Pada Gambar 1 terlihat bahwa kadar Fe organik pada aplikasi kompos lebih tinggi dibandingkan kontrol (tanpa aplikasi kompos) selama pengamatan.

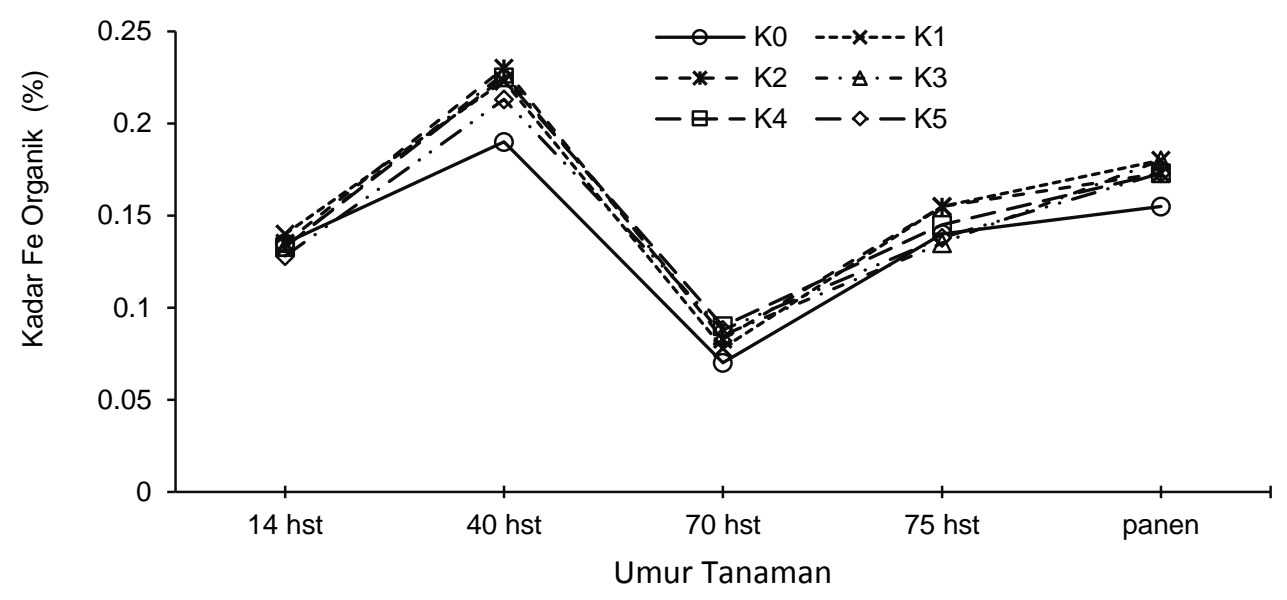

Gambar 1. Dimanika perubahan Fe organik akibat Aplikasi Kompos pada Tanah Rawa Lebak Poso (K0: Tanpa Kompos, K1: Kompos Jerami 100\%, K2 Kompos Jerami 75\% + Kompos KBK 25\%, K3: Kompos Jerami 50\% + Kompos KBK 50\%, K4: Kompos Jerami 25\% + Kompos KBK 75\%, K5: Kompos KBK 100\%)

Pada Gambar 1 terlihat bahwa puncak pembentukan Fe-p terjadi pada 40 HST. Hal tersebut mungkin berkaitan dengan tingginya kadar $\mathrm{C}$ organik (data tidak ditampilkan) dan tingkat reduksi $\mathrm{Fe}^{3+}$ menjadi $\mathrm{Fe}^{2+}$ yang tinggi. $\mathrm{Fe}^{2+}$ yang dibebaskan membentuk kompleks dengan anion organik dalam tanah. Menurut
Ponnamperuma et al. (1967) jumlah Fe terekstrak meningkat dengan meningkatnya jumlah bahan organik terdekomposisi, suhu, dan jumlah penyangga redoks tersedia, dan diperbesar oleh $\mathrm{pH}$ tanah awal yang rendah dan penambahan bahan organik terus-menerus (Becker dan Ash, 2005), serta ketiadaan senyawa dengan tingkat 
oksidasi yang lebih tinggi dari $\mathrm{Fe}(\mathrm{III})$ oksida (Ponnamperuma, 1972). Peningkatan reduksi mencapai puncak pada 2 - 8 minggu setelah penggenangan dan setelah itu menjadi konstan. Eusterhues et al. (2014) menyatakan ferrihydrite adalah $\mathrm{Fe}$ oksida amorf (kurang kristalin) yang mudah terselubungi oleh bahan organik secara alami di alam dan asam organik yang paling efektif dalam membentuk khelat mantap dengan ion logam adalah jenis di- dan trikarboksilat, serta hidroksil seperti asam sitrat (Stevenson dan Fitch, 1986).

Pengelolaan air secara macak-macak (I1) menyebabkan $\mathrm{Fe}$ organik lebih tinggi dibandingkan pengelolaan air secara intermiten (I2) yang ditunjukkan pada Gambar 2. Rendahnya $\mathrm{Fe}$ organik pada pengairan intermiten mungkin disebabkan oleh molekul air yang menyelaputi permukaan $\mathrm{Fe}$ menghalangi serangan asam organik pada Fe. Sementara itu, tingginya Fe-p juga disebabkan oleh penurunan $\mathrm{pH}$. $\mathrm{pH}$ pada pengairan macak-macak lebih rendah dari pengairan intermiten (data tidak ditampilkan). Schwertmann et al. (1986) menyatakan penurunan $\mathrm{pH}$ meningkatkan jumlah anion organik yang terjerap sebagai akibat peningkatan muatan positif bersih pada permukaan oksida Fe.

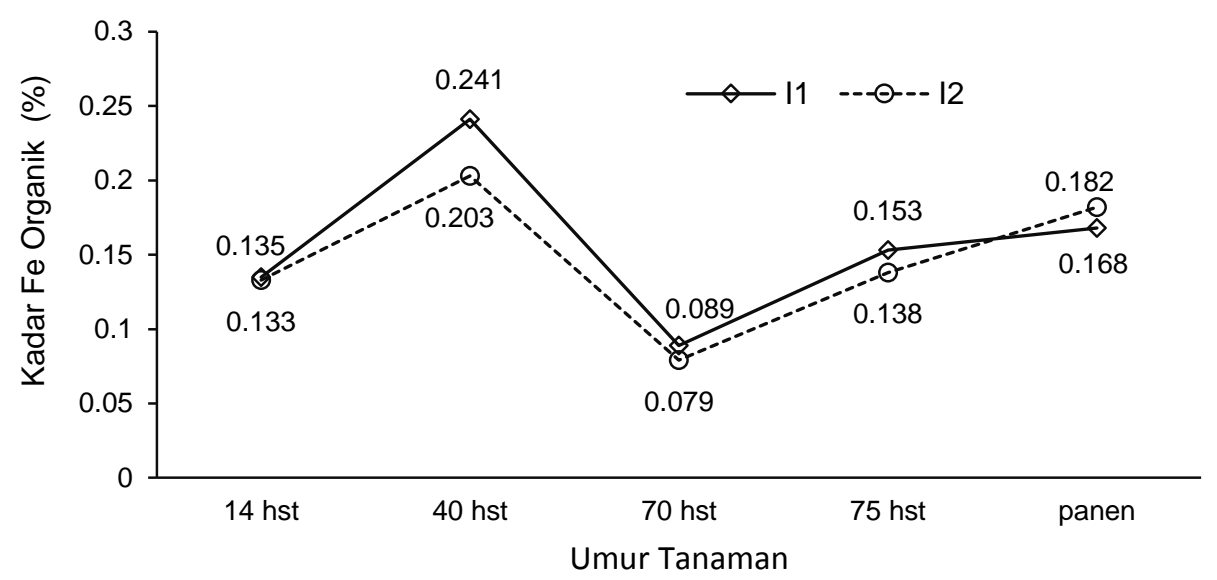

Gambar 2. Kadar Fe Organik akibat Pengelolaan Air Macak-macak (I1) dan Intermiten (I2)

\section{Kadar P tersedia}

Analisis keragaman menunjukkan bahwa aplikasi kompos dan interaksinya dengan pengelolaan air berpengaruh tidak nyata terhadap kadar $\mathrm{P}$ tsd (Bray-1), tetapi pengelolaan air pengaruhnya nyata pada umur 40, 70 dan 75 HST. Rerata $\mathrm{P}$ tsd pada pengairan macak-macak lebih tinggi dibandingkan pengairan intermiten (Gambar 3) dan berbeda nyata menurut uji Duncan pada umur 40, 70 dan 75 HST.

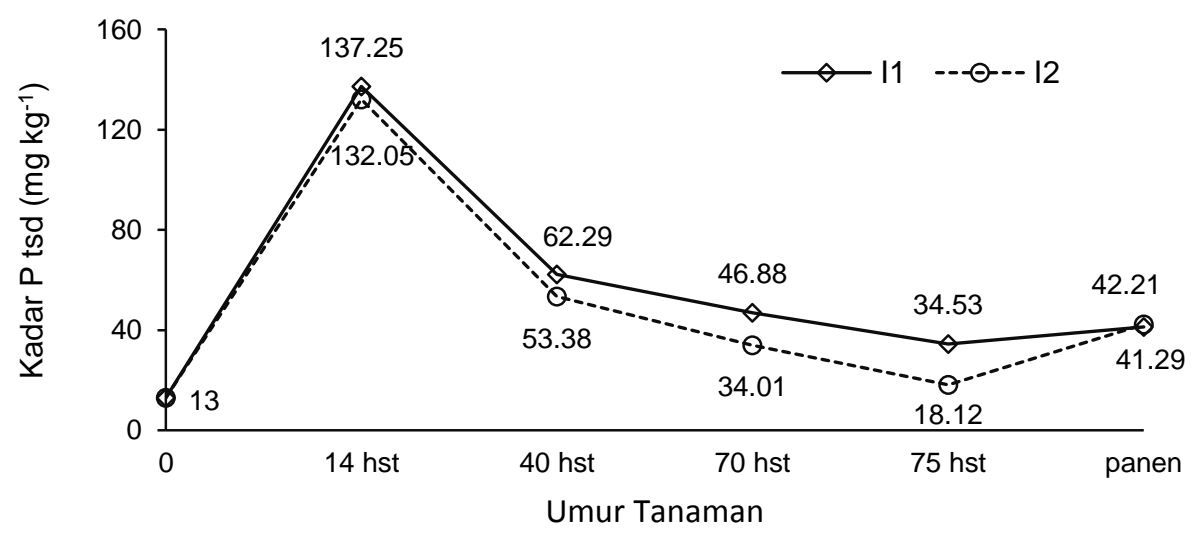

Gambar 3. Kadar P tsd (Bray-1) akibat Pengelolaan Air Macak-macak (I1) dan Intermiten (I2) 
Pada Gambar 3 terlihat bahwa terjadi peningkatan kadar $\mathrm{P}$ tsd yang luar biasa tinggi dari $\mathrm{P}$ tsd tanah awal (13 ppm). Juga tampak bahwa status ketersediaan P sangat tinggi ( $>15 \mathrm{mg} / \mathrm{kg}$ ) selama pengamatan. Hal tersebut terjadi karena penambahan pupuk $\mathrm{P}$ dan pembebasan $\mathrm{P}$ dari kompleks Fe. Pada 7 HST dilakukan pemupukan $180 \mathrm{~kg} / \mathrm{ha}$ SP-36. Menurut Reddy \& Delaune (2008), kelarutan $\mathrm{P}$ sebagai ion $\mathrm{H}_{2} \mathrm{PO}_{4}^{-}$mencapai puncak pada $\mathrm{pH}$ sekitar 4 - 6,5. pH tanah pada 14 HST sekitar 6,4 - 6,5 (data tidak ditampilkan), yaitu $\mathrm{pH}$ optimum bagi ketersediaan P. Hal itu menyebabkan ketersediaan $\mathrm{P}$ menjadi luar biasa tinggi pada 14 HST. Pada persamaan regresi linear sederhana terlihat bahwa peningkatan $\mathrm{P}$ tsd dipengaruhi oleh peningkatan $\mathrm{Fe}$ organik (Tabel 1).

Tabel 1. Persamaan Regresi Linear Sederhana Pengaruh Fe Organik terhadap P tersedia

\begin{tabular}{ll}
\hline \multicolumn{1}{c}{ Waktu pengamatan } & \multicolumn{1}{c}{ Persamaan regresi } \\
\hline 14 HST & P tsd $=1,176+976,086 \mathrm{Fe}-\mathrm{p}\left(\mathrm{r}=0,229^{\text {tn }}\right)$ \\
40 HST & $\mathrm{P}$ tsd $=-6,458+284,728 \mathrm{Fe}-\mathrm{p}\left(\mathrm{r}=0,748^{*}\right)$ \\
70 HST & $\mathrm{P}$ tsd $=-12,258+633,122 \mathrm{Fe}-\mathrm{p}\left(\mathrm{r}=0,666^{*}\right)$ \\
75 HST & $\mathrm{P}$ tsd $=-15,512+308,423 \mathrm{Fe}-\mathrm{p}\left(\mathrm{r}=0,242^{\mathrm{tn}}\right)$ \\
panen & $\mathrm{P}$ tsd $=-40,773+467,062 \mathrm{Fe}-\mathrm{p}\left(\mathrm{r}=0,704^{*}\right)$ \\
\hline
\end{tabular}

Keterangan: $\mathrm{Fe}-\mathrm{p}=\mathrm{Fe}$ organik, $\mathrm{P}$ tsd $=\mathrm{P}$ tersedia, $\mathrm{HST}=$ hari setelah tanam

Pada Gambar 2 juga terlihat bahwa kadar Fe organik pada pengairan macak-macak (I1) lebih tinggi dibandingkan pengairan intermiten (I2). Menurut Patrick dan Reddy (1978) kimia fosfat pada tanah tergenang dikaitkan dengan kimia $\mathrm{Fe}$ dan kondisi yang meningkatkan kelarutan $\mathrm{Fe}$ dalam tanah seringkali meningkatkan kelarutan P. Secara keseluruhan, kadar $\mathrm{C}$ organik pada pemberian kompos lebih tinggi dibandingkan kontrol (data tidak ditampilkan). Kadar C organik yang tinggi menghasilkan ligan organik yang tinggi pula dan mengompleks $\mathrm{Fe}$ menjadi $\mathrm{Fe}$ organik. Peningkatan P tsd yang disebabkan oleh peningkatan Fe-p berarti sumber $\mathrm{P}$ tsd berasal dari pertukaran ligan/anion. Anion organik mendesak anion fosfat dari permukaan $\mathrm{Fe}$ sehingga $\mathrm{P}$ menjadi tersedia. Menurut Hasegawa et al. (2012) pada konsentrasi ligan tinggi, kebanyakan $\mathrm{Fe}^{3+}$ dalam medium tumbuh membentuk kompleks FeL (L=ligan) terlarut. Yoshida (1981) menyatakan penggantian fosfat dari $\mathrm{Fe} / \mathrm{Al}$ fosfat oleh anion organik dapat meningkatkan ketersediaan P.

Pengaruh aplikasi kompos terhadap $\mathrm{P}$ tsd ditunjukkan pada Gambar 4. Pada gambar tersebut terlihat bahwa kadar P tsd pada aplikasi kompos lebih tinggi dibandingkan kontrol (tanpa aplikasi kompos) selama pengamatan.

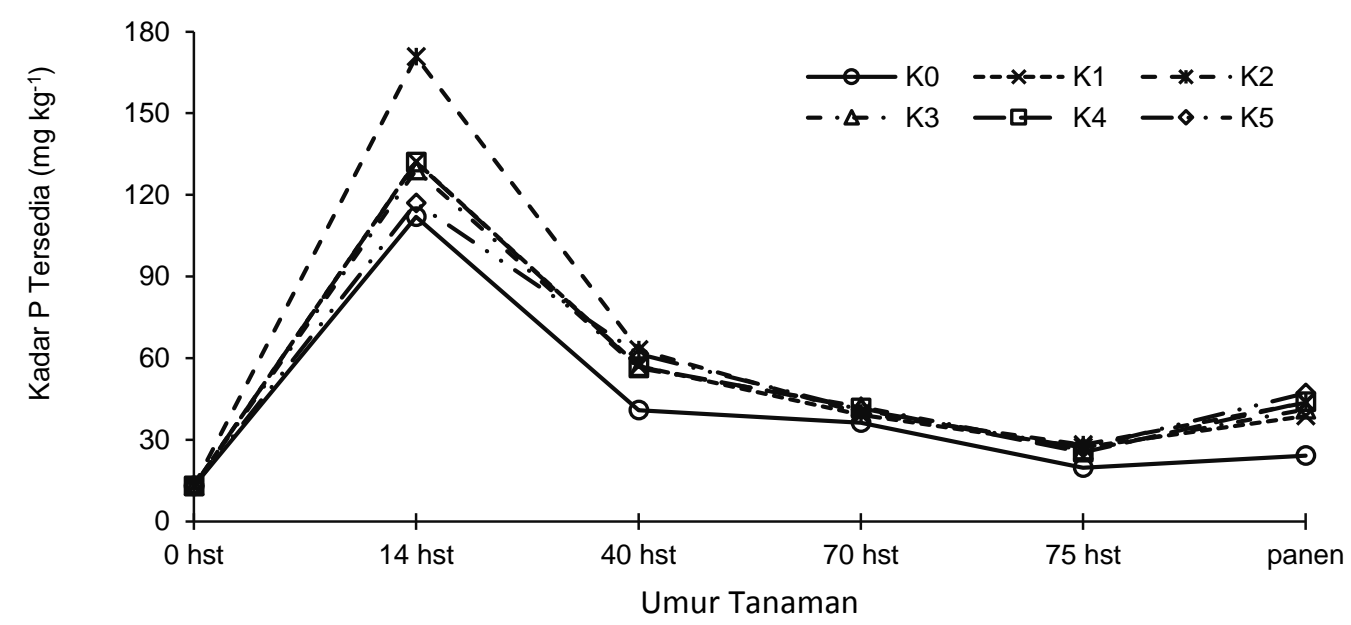

Gambar 4. Dimanika Perubahan P tersedia akibat Aplikasi Kompos pada Tanah Rawa Lebak Poso (K0: Tanpa Kompos, K1: Kompos Jerami 100\%, K2 Kompos Jerami 75\% + Kompos KBK 25\%, K3: Kompos Jerami 50\% + Kompos KBK 50\%, K4: Kompos Jerami 25\% + Kompos KBK 75\%, K5: Kompos KBK 100\%) 
Peningkatan $\mathrm{P}$ tsd akibat aplikasi kompos terjadi karena asam organik yang dibebaskan dari kompos mendesak $\mathrm{P}$ yang terikat pada $\mathrm{Fe}$ tanah sehingga kadar $\mathrm{P}$ tsd tanah lebih tinggi. Tanah yang mengandung bahan organik menurunkan kapasitas adsorpsi $\mathrm{P}$ karena hasil langsung kompetisi loka serapan antar fosfat dan ligan organik (Moazed et al., 2010). Menurut Murthy et al. (2010) pemberian kompos dan pupuk kimia sesuai rekomendasi meningkatkan ketersediaan $P$. Marschner (2012) menyatakan bahwa ligan organik meningkatkan ketersediaan $\mathrm{P}$ melalui pertukaran anion, yaitu melalui penggantian $\mathrm{P}$ dari loka pengikatan. Jerapan $\mathrm{P}$ bersaing dengan anion organik. Anion organik menyebabkan permukaan penjerap lebih negatif sehingga menurunkan jerapan fosfat.

\section{KESIMPULAN}

Dari uraian di atas dapat disimpulkan bahwa aplikasi kompos pada tanah sawah rawa lebak di Poso meningkatkan kadar $\mathrm{Fe}$ organik dan $\mathrm{P}$ tersedia dalam tanah. Kadar $\mathrm{Fe}$ organik dan $\mathrm{P}$ tersedia dalam tanah pada pengelolaan air secara macak-macak lebih tinggi dibandingkan pengelolaan air secara intermiten. Peningkatan $\mathrm{Fe}$ organik cenderung meningkatkan $\mathrm{P}$ tersedia dalam tanah sawah rawa lebak di Poso.

\section{DAFTAR PUSTAKA}

Abifarin, A.O. 1988. Grain Yield Loss Due to Iron Toxicity. WARDA Technical Newsletter. 8(1), 1-2.

Andiantoro, S., \& Slamet, M. 1991. Keragaan Empat Varietas Padi di Lahan Sawah Bermasalah Keracunan Fe yang dipupuk P dan K. Bul Pen Pertan Maros. 6(3), 85-88.

Audebert, A. 2006. Diagnosis of Risk and Approaches to Iron Toxicity Management in Lowland Rice Farming. Africa Rice Center (WARDA).

Becker, M., \& Ash, F. 2005. Iron Toxicity in Rice: Conditions and Management Concepts. $J$. plant Nutr. Soil Sci. 168, 558 - 573.

Benckiser, G., Ottow, J.C.G., Santiago, S., \& Watanabe, I. 1982. Physicochemical Characterization of Iron Toxic Soil in Some Asian Countries. IRRI Res. Pap. Ser 85:1982.
BPS (Badan Pusat Statistik). 2011. Kabupaten Poso Dalam Angka 2011. BPS Kabupaten Poso bekerjasama dengan Bappeda Kabupaten Poso.

Dobermann, A., \& Fairhurst, T.H. 2000. Rice: Nutrinet Disorders \& Nutrient Management. Potash \& Phosphate Institute (PPI), Potash \& Phosphate Institute of Canada (PPIC) \& International Rice Research Institute (IRRI).

Ethan, S., Odunze, A.C., Abu, S.T., \& Iwuafor, E.N.O. 2011. Effect of Water Management and Nitrogen Rates on Iron Concentration and Yield in Lowland Rice. Agric. Boil. J. N. Am. 2(4), 622-629.

Eusterhues, K., Hädrich, A., Neldhardt, J., Küsel, K., Keller, T.F., Jandt, K.D., \& Totsche, K.U. 2014. Reduction of ferrihydrite with adsorbed and coprecipitated organic matter: microbial reduction by Geobacter bremensis vs abiotic reduction by $\mathrm{Na}$-dithionite. Biogeosciences. $11,4953-4966$.

Fairhurst, T., Dobermann, A., Quijano-Guerta, C., \& Balasubramanian, V. 2002. Mineral Deficiencies and Toxicities. In: T. Fairhurst \& C. Witt (eds). Rice, a Practical Guide to Nutrient Management. Potash \& Phosphat Institute (PPI). Potash \& Phosphat Intitute of Canada (PPIC) and IRRI.

Gunawardena, I., Virmani, S.S., \& Sumo, F.J. 1982. Breeding Rice for Tolerance to Iron Toxicity. Oryza. 19(1), 5-12.

Hasegawa, H., Rahman, M.M., Kadohashi, K., Rahman, M.A., Takasugi, Y., Tale, Y., \& Maki, T. 2012. Significance of the concentration of chelating ligand on $\mathrm{Fe}^{3+}$ solubility, bioavailability, and uptake in rice plant. J. Plant Physiology and Biochemistry. 58, 205-211.

Havlin, J.L., Beaton, J.D., Nelson, S.L., \& Nelson, W.L. 2005. Soil Fertility and Fertilizers: an Introduction to Nutrient Management. Pearson Prentice Hall. New Jersey.

Indradewa, D., Maas, A., Noor, M., \& Khairullah, I. 2010. Evaluasi Ketahanan Padi Sawah Terhadap Keracunan Besi (< 500 ppm) melalui Pemupukan Organik (10 ton/ha) untuk Mencapai Hasil Tinggi (> 6 ton/ha) di Lahan Sulfat Masam Pasang Surut. Laporan akhir Hasil Kegiatan. LPPM UGM bekerjasama 
dengan Badan Penelitian dan Pengembangan Pertanian.

Ismunadji, M. 1990. Alleviating iron toxicity in lowland rise. J. IARD. 12 (4), 67-72

Ismunadji, M., Hakim, L.N., Zulkarnain, I., \& Yasawa, F. 1973. Physiological dedisease of Rice in Cihea. Contr. Cent. Res. Inst. Agric. Pusat Penelitian dan Pengembangan Tanaman Pangan Bogor. 4:10

Marschner, P. 2012. Mineral Nutrition of Higher Plants. $3^{\text {th }}$ ed. Academic Press, Elsevier Ltd. Singapore.

Kirk, G.J.D. 2004. The Biochemistry of Submerged Soils. Chichester, UK: John Wiley \& Sons, $291 \mathrm{p}$.

Masajo, T.M., Alluri, K., Abifarin, A.O., \& Jankiram, D. 1986. Breeding for High and Stable Yields in Africa. In. the Wetlands and Rice in Subsaharan Africa. ASR Juo and JA Lowe (Eds.) Ibadan, Nigeria. Int. Inst. Of Trop. Agric. P 107-114.

Moazed, H., Hoseini, Y., Naseri, A.A., \& Abbasi, F. 2010. Determining phosphorus adsorption isotherm in soil and its relation to soil characteristic. J. Food Agric. Envir. 8(2), 1153-1157.

Murthy, R.K., Raveendra, H.R., \& Reddy, T.B.M. 2010. Effect of chromolaena and parthenium as green manure and their compost on yield, uptake and nutrient use efficiency on typic Paleustalf. EJBS. 4(1), 41-45.

Mowidu, I., Sunarminto, B.H., Purwanto, B.H., \& Utami, S.N.H. 2015. Kadar Fe Total pada Tanah Sawah Rawa Lebak di Kabupaten Poso. Jurnal Agropet. 12(1), 1-5.

Nawaz, M.F., Bourie, G., Gul, S., Trolard, F., Mouret, J.C., \& Tanvir, M.A. 2014. Effect of post-harvest management practices on the stability of iron minerals in rice culture. Pak. J. agric. Sci. 51(4), 861-866.

Noor, M. 2007. Rawa Lebak: Ekologi, Pemanfaatan dan Pengembangannya. PT Rajagrafindo Persada. Jakarta.

Ottow, J.C.G., Benckiser, G., \& Watanabe, I. 1982. Iron Toxicity of Rice as a Multiple Nutrition Soil Stress. In: Proc. of Symposium on Tropical Agriculture Research. Trop.
Agric. Res. Series No. 15. Trop.1 Agric. Res. Centre. Ministry of Agric. Forestry and Fisheries, Japan, p. 167-179.

Patrick, W.H., \& Reddy, C.N. 1978. Chemical Change in Rice Soils in International Rice Research Institute. Soils and Rice. Los Banos. Philippines.p 36-380.

Ponnamperuma, F.N. 1972. The Chemistry of Submerged Soils. Reprinted from Advance in Agronomy. Vol. 24. Academic Press, Inc. $\mathrm{P}$ 29-96

Ponnamperuma, F.N. 1977. Behavior of Minor Elements in Paddy Soils. IRRI Research Paper Series. IRPS No. 8 May, 1977. The International Rice Research Institute. Manila, Philippines.

Ponnamperuma, F.N. 1994. Evaluation and Improvement of Lands for Wetland Rice Production. P 3-19. In: Senandhira, D. (ed.). Rice and Problem Soils in South and Southeast Asia. IRRI Discussion Paper Series No. 4. IRRI, Manila, the Philippines.

Ponnamperuma, F.N., Tianco, E.M., \& Loy, T. 1967. Redox Equilibria in Flooded Soils: the Iron Hydroxides Systems. Soil Science. 103(6), 374-382.

Prasad, R., \& Power, J.F. 1977. Soil Fertility Management for Sustainable Agriculture. CRC Lesi Publisher. New York.

Sahrawat, K.L. 2000. Elemental composition of the Rice Plant as affected by Iron Toxicity under Field Condition. Commun. Soil Sci. Plant Anal. 31(17/18), 2819-2827.

Sahrawat, K.L. 2004. Ammonium Production in Submerged Soils and Sediment: the Role of Reducible Iron. Journal Communication in Soil Sci. and Plant Analysis. 35(3/4), 394-411.

Sahrawat, K.L. 2012. Soil fertility in flooded and non-flooded irrigated systems. ICRISAT. 58(4), 423-436.

Schwertmann, U., Kodama, H., \& Fischer, W.R. 1986. Mutual Interaction between Organics and Iron Oxides. In Interaction of Soil Minerals with Natural Organics and Microbes. Huang, P.M. \& M. Schnitzer (Editors). Soil Science Society of America, Inc. Madison, Wisconsin, USA. p 223-250. 
Stevenson, F.J., \& Fitch, A. 1986. Chemistry of Complexation of Metal Ions with Soil Solution Organics. In Interaction of Soil Minerals with Natural Organics and Microbes. Huang, P.M. $\&$ M. Schnitzer (Editors). Soil Science Society of America, Inc. Madison, Wisconsin, USA. P $29-58$

Suparwoto \& Waluyo. 2009. Peningkatan Pendapatan Petani di Rawa Lebak melalui
Penganekaragaman Komoditas. Jurnal Pembangunan Manusia. 7(1), 1-9.

Yamauchi, M. 1989. Rice Bronzing in Nigeria Caused by Nutrient Imbalances and Its Control by Potassium Sulphate Application. Plant and Soil. 117(2), 275-286

Yoshida, S. 1981. Fundamentals of Rice Crop Science. The International Rice Research Institute. Los Banos, Languna, Philippines. 